\title{
EFFECT OF SEED STORAGE PERIODS, CONDITIONS AND MATERIALS ON SEED QUALITY OF SOME SOYBEAN CULTIVARS
}

\author{
KANDIL A.A., SHARIEF A.E. AND SHETEIWY M.S.* \\ Department of Agronomy, Faculty of Agriculture, Mansoura University, Egypt. \\ ${ }^{*}$ Corresponding Author: Email-salahco_2010@mans.edu.eg
}

Received: March 09, 2013; Accepted: April 04, 2013

\begin{abstract}
In order to examine the effect of storage period, storage conditions and storage materials on seed quality of some soybean cultivars. A Laboratory experiment was conducted in Agronomy Department, Fac. of Agric., Mansoura Univ., Egypt during 2011 and 2012. The results showed that acid number, peroxide number and electrical conductivity (dSm-1)were increased with the period of ageingwere increased. The obtained results indicated that Giza 22cultivar exceeded other cultivars in electrical conductivity and moisture percentage. Giza 35 cultivar exceeded the other cultivars in acid number and peroxide number. Crawford cultivar exceeded the other cultivars in oil percentage. Storage under refrigerator conditions at $10^{\circ} \mathrm{C} \pm 1$ exceeded storage under ambient conditions in oil percentage and moisture percentage. Storage under ambient conditions exceeded storage under refrigerator conditions at $10^{\circ} \mathrm{C} \pm 1$ in acid number, peroxide number and electrical conductivity. Acid number and peroxide number significantly affected by storage material. Storage soybean cultivars as seeds or pods in plastic bags recorded lowest values of peroxide and acid number compared with other package materials. Results clearly showed that oil percentage, moisture percentage, acid number, peroxide number and electrical conductivity significantly affected by the varies interactions.
\end{abstract}

Keywords- Soybean, cultivars, storage, viability, deterioration, seed vigor and periods

Citation: Kandil A.A., Sharief A.E. and Sheteiwy M.S. (2013) Effect of Seed Storage Periods, Conditions and Materials on Seed Quality of Some Soybean Cultivars. International Journal of Agriculture Sciences, ISSN: 0975-3710 \& E-ISSN: 0975-9107, Volume 5, Issue 1, pp.-339346 .

Copyright: Copyright@2013 Kandil A.A., et al. This is an open-access article distributed under the terms of the Creative Commons Attribution License, which permits unrestricted use, distribution and reproduction in any medium, provided the original author and source are credited.

\section{Introduction}

Both storage conditions and duration are important factors affecting soybean seed quality and the degree of biochemical changes in seed. In Egypt, soybean the most important crop and being the edible oil. Seed quality is an imperative parameter for commercialization and processing of the seed and can affect the value of the product and its derivatives [2]. Changes that occur in seed during ageing are significant in terms of seed quality among other things, also implies seed longevity [20]. Changes arising in seed during are very significant with regard to quality and longevity of seed. Characteristics of oily plants seed composition are relatedto specific processes occurring in seed during storage [14]. Seed quality during storage depend upon the initial quality of seed and the manner in which it is stored. The rapid seed deterioration of soybean is thought to be due to lipid peroxidation, subsequently resulting in loss of seed viability [27].

Changes in seed during ageing are significant in terms of seed quality, among other things, also implies seed longevity [20]. Balesevic-Tubicet, et al. [8] showed that defense of seed qualityhang onageing condition and duration. Khaliliaqdamet, et al. [19] suggested that variations occurred with the viability constants of a seed deterioration model between the soybean cultivars. Different periods of seed ageing, as well as storage conditions adversely affected the seed quality [30]. Similar inferences was reported by
Sharma, et al [26], Simic, et al [29] and Vijay, et al [35].

Differences in oil affected by storage longevity were significant among tested crops and genotypes within crops. Storage longevity was negatively related with oil percentage. At storage conditions at $12^{\circ} \mathrm{C} / 60 \%$, decreasing of seed oil content than in storage conditions at $25^{\circ} \mathrm{C} / 75 \%$ [28]. The amount of electrolytes in the soaked water increased as the period of time and the temperature of storage were increased. The temperature at which soybean seeds remain during storage may affect the amount of electrolytes in the soaked water and consequently the results of the electrical conductivity test [33]. Vijay, et al. [35] incubated soybean seeds at two different temperatures of $34^{\circ} \mathrm{C}$ and $40^{\circ} \mathrm{C}$ for varying times. They indicated that soybean viability decreased by increasing storage temperature.

A significant difference between soybean genotypes (Sb1, Sb2, $\mathrm{Sb3}, \mathrm{Sb} 4, \mathrm{Sb} 5$ and Sb6) in oil percentage, acid number, peroxide number and moisture percentage. These differences between genotypes might be due to the genetic factors and seed chemical composition influence the expression of seed deterioration and vigor decline [30]. Khaliliaqdamet, et al. [19] reported that initial viability was same $100 \%$ among DPX and Sahar cultivars. Electrical conductivity had no significant difference between DPX and Sahar cultivars but in Shahar, were higher than DPX and EC in Sahar was lower. Similar conclusions were reported by Kalavathi, et al [18], 
Simic, et al [29], Venkatareddy, et al [32].

In case of quality characters of soybean seed decreases all cases but the rate of deterioration is highest in cloth bag [22]. Seeds were stored in Metallized film bags and Aluminum foil bags observed highly standard quality and seed vigor, and keep water activity and seed moisture content in low level could delay seed quality deterioration followed by Polypropylene bags and woven bag [10]. Seeds were stored in aluminums foil bags observed highly seedling vigor and keep moisture content in low level could delay seed deterioration followed by polyethylene and wheat bags [31]. Sorghum seeds stored inside gene bank and freezer regardless of the packaging materials and type of accession retain their viability [24]. Similar results was obtained by $[6,9,25]$. Chuansin, et al. [10] found that soybean seeds were stored in Metallized film bags and Aluminum bafoil gs keep water activity and seed moisture content in low level could delay seed quality deterioration followed by Polypropylene bags and woven bag. The oil peroxide index differed significantly among samples due to the interaction between moisture content, temperature and storage period [3]. The objectives of this research were aimed to determine the effects of storage periods, storage conditions and materials on seed quality characters of some soybean cultivars.

\section{Materials and Methods}

A laboratory experiment was conducted at experimental seed testing laboratory of Agronomy Department, Faculty of Agriculture, Mansoura University, Egypt during 2011 and 2012. The objectives of this investigation were aimed to investigate the response of some soybean cultivars i.e. Giza 21, Giza 22, Giza 35, Giza 111 and Crawford to storage periods i.e. 3,6,9 and 12 months, storage conditions i.e. ambient conditions and refrigerator conditions at $10^{\circ} \mathrm{C} \pm 1$ as well as storage materials i.e. seed with cloth bags, seed with plastic bags, pods with cloth bags and pods with plastic bags on seeds quality characters.

\section{Treatments and Experimental Design}

Treatments were arranged in factorial experimental in completely randomize design, consisted of totally 160 treatments combinations involving tow storage conditions i.e. ambient conditions and refrigerator conditions at $10^{\circ} \mathrm{C} \pm 1$, four different kinds of package materials i.e. seed with cloth bags, seed with plastic bags, pods with cloth bags and pods with plastic bags of five soybean cultivars i.e. Giza21, Giza22, Giza35, Giza 111 and Crawford. Four storage periods i.e. 3,6,9 and 12 months were used. Soybean (Glycine Max L. Merr.) cultivars were harvested in October 2011, cleaned from dust and dirt then dried and processed for storage. Every three months, from a total 12 months of storage, electrical conductivity, acid number, peroxide number, oil percentage and moisture percentage were evaluated.

\section{Studied Characteristics}

The following seed quality characters were studied as following:

\section{Oil Percentage (\%)}

Soxhelt apparatus was used for determination of ether extract percent, heating by electric heaters; cold water was used through the condenser. Petroleum ether $\left(60-80^{\circ} \mathrm{C}\right)$ was preferred for extractions which continued for not less than eight hours (rate of siphoning was 6-7 /hr.) according to AOAC [1]. Moreover, oil percentage was calculated by multiplying ether extract percent $\times$ yield of dry matter $(\mathrm{g})$.

\section{Acid Number}

Acid value was determined according to AOAC [1]. A known weight of sample ( $\mathrm{g}$ ) was dissolved in $20 \mathrm{ml}$ ethylalcohol then the contents of the flask were shaken for one minute, then titrated with aqueous potassium hydroxide $(0.1 \mathrm{~N})$ in the presence of phenolphthalein as indicator. The acid value was calculated according to the following equation $[\mathrm{Eq}-1]$ :

$$
\text { AcidValue }(A . V .)=\frac{V \times N \times 56.1}{W}
$$

Where, $\mathrm{V}=$ volume of $\mathrm{KOH}$ required to neutralize the free fatty acids, $\mathrm{N}=$ normality of $\mathrm{KOH}$ and $\mathrm{W}=$ weight of sample.

\section{Peroxide Number}

Peroxide value was determined as reported by AOAC [1]. A known weight of oil sample $(\mathrm{g})$ was dissolved in $30 \mathrm{ml}$ of glacial acetic acid:

Chloroform mixture $(2: 1, \mathrm{v} / \mathrm{v})$, then one $\mathrm{ml}$ of freshly prepared saturated potassium iodide solution was added. The content of the flask were allowed to stand with occasional shaking for exactly $1 \mathrm{~min}$ and $30 \mathrm{ml}$ of distilled water were added.

The liberated iodine was titrated with sodium thiosulphate solution $(0.1 \mathrm{~N})$ until the yellow color had almost disappeared. The titration was continued after adding $1 \mathrm{ml}$ of $1 \%$ starch solution as an indicator until the blue color has just disappeared.

The following equation [Eq-2] was used for calculation of peroxide value expressed as mill equivalents of oxygen / $\mathrm{g}$ oil:

$$
\text { PeroxideValue }=\frac{\mathrm{V} \times \mathrm{N}}{\mathrm{W}} \times 1000
$$

Where, $V=$ volume of sodium thiosulphte used for sample, $N=$ normality of sodium thiosulphate solution and $\mathrm{W}=$ weight of oil sample.

\section{Electrical Conductivity of Seed Leachate ( $\left.\mathrm{dSm}^{-1}\right)$}

Five grams of seeds in four replications were surface sterilized with $\mathrm{HgCl}_{2} 1 \%$ solution and thoroughly washed in distilled water, later seeds were soaked in $25 \mathrm{ml}$ distilled water and kept at $25 \pm 1^{\circ} \mathrm{C}$ for $24 \mathrm{hr}$. The leachate was decanted to another container and volume was made up to $25 \mathrm{ml}$ by adding distilled water. The electrical conductivity of seed leachate was measured with electrical conductivity bridge and expressed in $\mathrm{dSm}^{-1}[16]$.

\section{Moisture Percentage (\%)}

The moisture percentage of the seed was calculated according to the International Seed Testing Association (ISTA) rules [16] by hot air oven method maintaining $103^{\circ} \mathrm{C} \pm 2^{\circ} \mathrm{C}$ for $17 \mathrm{hr}$. and then at $105^{\circ} \mathrm{C}$ till constant dry weight. The moisture content was calculated on wet basis and expressed in percentage by using the following formula [Eq-3]:

$$
\text { Moisture Percentage }(\%)=\frac{(M 2-M 3)}{(M 2-M 1)} \times 100
$$

Where, $\mathrm{M} 1=$ Weight of empty moisture tin in $(\mathrm{g}), \mathrm{M} 2=$ Weight of moisture tin and seed material before drying $(\mathrm{g})$ and $\mathrm{M} 3=$ Weight of moisture tin and seed material after drying $(\mathrm{g})$.

\section{Result and Discussion \\ Storage Periods Effects}

The results showed that oil percentage and moisture percentage 
were decreased as storage periods were increased as shown in [Table-1]. While, acid number, peroxide number and electrical conductivity were increased as storage periods were increased. Before storage treatment significantly exceeded the other storage periods in oil percentage and moisture percentage followed by storage for 3 months. While, storage for 12 months recorded lowest oil percentage and moisture percentage. It could be concluded that increasing storage periods from 6 and 12 months decreased oil percentage by 12.99 and $17.58 \%$, respectively compared with before storage treatment. Increasing storage periods from 3, 6, 9 and 12 months decreased moisture percentage by $0.42,1.38,0.95$ and $2.45 \%$, respectively compared with before storage treatment. Increasing storage periods from $3,6,9$ and 12 months increased electrical conductivity by $7.28,11.57,13.96$ and $18 . \%$, respectively compared with before storage treatment. Increasing storage periods from 6 and 12 months increased acid number by 14.39 and $23.59 \%$, respectively compared with before storage treatment. Increasing storage periods from 6 and 12 months increased peroxide number by 12.61 and $30.27 \%$, respectively compared with before storage treatment. Decrease of seed quality is connected with biochemical changes in seeds of oil crops. These seeds had a rapid deterioration due to autoxidation of lipids and the increase of the content of free fatty acids during storage period. The longer seeds storage period increases intensity of seeds ageing [10]. These results are in good agreement with many researchers $[5,7,12,13,15,17,19]$.

\section{Storage Cultivars Effects}

Results in [Table-1] revealed that Giza 35 cultivar surpassed other cultivars in acid number and peroxide number. Giza 21 cultivar recorded the lowest moisture percentage. Giza 22cultivar recorded the lowest peroxide number and acid number. Giza 35 cultivar recorded the lowest oil percentage. Giza 35cultivar surpassed Giza 21, Giza22, Giza 111 and Crawford cultivars in acid number by 3.31 , 18.96, 10.68 and 4.05\%, respectively. Giza 35 cultivar surpassed Giza 21, Giza22, Giza 111 and Crawford cultivars in peroxide number by $12.13,25.10,8.13$ and $8.27 \%$, respectively. In this respect, Tatic, et al [30] stated that there was significant differences between soybean genotypes ( $\mathrm{Sb} 1, \mathrm{Sb} 2, \mathrm{Sb} 3, \mathrm{Sb} 4, \mathrm{Sb} 5$ and Sb6) in oil percentage, acid number, peroxide number and moisture percentage. These differences between genotypes might be due to the genetic factors and seed chemical composition influence the expression of seed deterioration and vigor decline. In addition, Doijoide [11] stated that the storability of different soybean cultivars is also regulated by initial seed quality, physical and chemical composition of seed as different cultivars possess different physical structure and chemical composition which determine the quality of seed in storage. Moreover, Gupta and Aneja [4] indicated that decreases in oil content between soybean cultivars may be due to age induced depletion phenomenon, improper storage environments and higher activity of storage fungi. These results are in good accordance with those obtained by Balesevic-Tubic, et al [7], Chuansin, et al [10], Erandes, et al [13] Jamro, et al [17] Khaliliaqdam, et al [19] Tatic, et al [30].

\section{Storage Conditions Effects}

The results in [Table-1] showed that a significant effect of storage conditions on average of oil percentage, acid and peroxide number and electrical conductivity. Storage under refrigerator conditions at $10^{\circ} \mathrm{C}$ surpassed ambient conditions in oil percentage by $4.71,5.85$, $11.67,7.77$ and $2.92 \%$, respectively. While, storage under ambient conditions surpassed refrigerator conditions at $10^{\circ} \mathrm{C}$ in acid number, peroxide number and electrical conductivity by $26,8.29$ and $2.77 \%$, respectively. In this regard, Arif [6] recorded that highest seed quality was in seed stored at $4^{\circ} \mathrm{C}$ than room temperature. Moreover, Vijay and Dadlani [35] incubated soybean seeds at two different temperatures of $34^{\circ} \mathrm{C}$ and $40^{\circ} \mathrm{C}$ for varying times. They indicated that soybean viability decreased by increasing storage temperature. These results are in good harmony with those obtained by Balesevic-Tubic, et al [7], Erandes, et al [13] Jamro, et al [17], Khaliliaqdam, et al [19], Mohammadi, et al [21], Vieira, et al [33].

Table 1- Averages of oil percentage (\%), acid number, peroxide number, electrical conductivity $\left(\mathrm{dSm}^{-1}\right)$ and moisture percentage

(\%) as affected by storage periods, soybean cultivars, storage conditions, package materials and their interactions.

\begin{tabular}{|c|c|c|c|c|c|}
\hline Characters & $\begin{array}{l}\text { Oil } \\
(\%) \\
\text { orage p }\end{array}$ & $\begin{array}{c}\text { Acid } \\
\text { Number } \\
\text { periods (n }\end{array}$ & $\begin{array}{l}\text { Peroxide } \\
\text { Number } \\
\text { months) }\end{array}$ & $\begin{array}{l}\text { Electrical } \\
\text { Conductivity } \\
\left(\mathrm{dSm}^{-1}\right)\end{array}$ & $\begin{array}{c}\text { Moisture } \\
(\%)\end{array}$ \\
\hline Before storage & 22.86 & 4.34 & 5.32 & 1.91 & 9.38 \\
\hline 3 months & - & - & - & 2.06 & 9.34 \\
\hline 6 months & 19.89 & 5.07 & 6.47 & 2.16 & 9.25 \\
\hline 9 months & - & - & - & 2.22 & 9.29 \\
\hline 12 months & 18.84 & 5.68 & 7.63 & 2.27 & 9.15 \\
\hline LSD $5 \%$ & 0.19 & 0.04 & 0.08 & 0.01 & 0.12 \\
\hline \multicolumn{6}{|c|}{ V-Soybean cultivars } \\
\hline Giza 21 & 20.69 & 5.25 & 6.37 & 1.99 & 9.17 \\
\hline Giza 22 & 20.37 & 4.4 & 5.43 & 2.24 & 9.42 \\
\hline Giza 35 & 20.35 & 5.43 & 7.25 & 2.11 & 9.18 \\
\hline Giza 111 & 20.41 & 4.85 & 6.66 & 2.1 & 9.34 \\
\hline Crawford & 20.82 & 5.21 & 6.65 & 2.2 & 9.28 \\
\hline LSD 5\% & 0.25 & 0.05 & 0.1 & 0.01 & 0.12 \\
\hline \multicolumn{6}{|c|}{ C-Storage conditions } \\
\hline Ambient conditions & 20.22 & 5.16 & 6.75 & 2.16 & 9.24 \\
\hline Refrigerator conditions $\left(10^{\circ} \mathrm{C} \pm 1\right)$ & 20.83 & 4.9 & 6.19 & 2.1 & 9.32 \\
\hline F- test & ** & ** & $* *$ & $\star *$ & NS \\
\hline \multicolumn{6}{|c|}{ P.Package materials } \\
\hline Pods in plastic bags & 20.42 & 4.99 & 6.49 & 2.12 & 9.35 \\
\hline Pods in cloth bags & 20.61 & 5.16 & 6.53 & 2.12 & 9.26 \\
\hline Seed in plastic bags & 20.57 & 4.89 & 6.49 & 2.13 & 9.29 \\
\hline Seed in cloth bags & 20.52 & 5.08 & 6.38 & 2.13 & 9.22 \\
\hline LSD $5 \%$ & NS & 0.08 & 0.09 & NS & NS \\
\hline \multicolumn{6}{|c|}{ F-test Interactions } \\
\hline $\mathrm{V} \times \mathrm{S}$ & ** & ** & ** & $* *$ & NS \\
\hline$S \times C$ & ** & ** & ** & $* *$ & ** \\
\hline$V \times C$ & $* *$ & NS & NS & ** & NS \\
\hline$V \times C \times S$ & NS & NS & NS & * & NS \\
\hline$S \times P$ & NS & $* *$ & * & NS & NS \\
\hline$V \times P$ & NS & ** & $* *$ & $* *$ & NS \\
\hline$V \times S \times P$ & NS & ** & * & * & NS \\
\hline $\mathrm{C} \times \mathrm{P}$ & NS & NS & NS & * & NS \\
\hline$S \times C \times P$ & NS & NS & NS & NS & NS \\
\hline$V \times C \times P$ & NS & NS & NS & NS & NS \\
\hline$V \times C \times S \times P$ & NS & NS & NS & NS & NS \\
\hline
\end{tabular}

\section{Storage Package Materials Effects}

The results in [Table-1]showed that a significant effect of package materials on the average of acid number and peroxide number. The results showed that highest value of acid number was obtained from storage soybean pods or seed in cloth bags. However, lowest value of acid number was obtained from storage soybean cultivars pods or seeds in plastic bags. Highest value of peroxide number was obtained from storage soybean pods in cloth bags. However, lowest value of peroxide number was obtained from storage soy- 
bean cultivars seeds in cloth bags. In this regard, Chuansin, et al [10] showed that seeds were stored in Metallized film bags and Aluminum foil bags observed highly standard quality and seed vigor, and keep water activity and seed moisture content in low level could delay seed quality deterioration followed by Polypropylene bags and woven bag. Moreover, Tatipata [31] stated that seeds were stored in aluminums foil bags observed highly seedling vigor and keep moisture content in low level could delay seed deterioration followed by polyethylene and wheat bags. These results are in harmony with those reported by Arefi and Abdi [5], Erandes, et al [13], Khaliliaqdam, et al [19], Tatipata [31].

\section{Interaction Effects}

\section{Interaction between Soybean Cultivars and Storage Periods}

Highest electrical conductivity was obtained from storage Giza 22 and Crawford cultivars for 12 months without significant differences between them. Lowest values of electrical conductivity were recorded from Giza 35 and Giza 21 cultivars before storage without significant differences between them [Fig-1]. The results clearly indicated that highest oil percentage was obtained from Giza 21 cultivar before storage followed by Giza 21 cultivar storage for 6 months. While, lowest oil percentage were recorded from storage Giza 21 and Giza 22 cultivar storage for 12 months without significant between them [Fig-2].

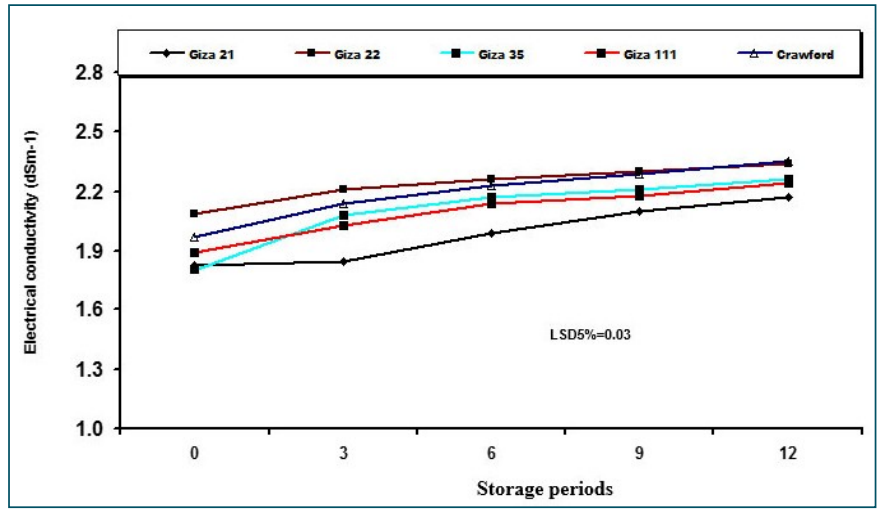

Fig. 1- Averages of electrical conductivity $\left(\mathrm{dSm}^{-1}\right)$ as affected by the interaction between soybean cultivars and storage periods

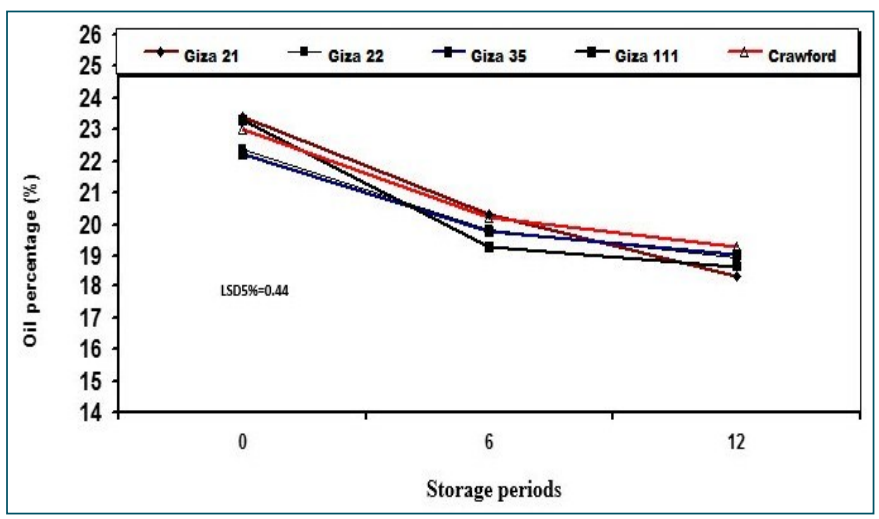

Fig. 2- Averages of oil percentage (\%) as affected by the interaction between storage periods and soybean cultivars

The results clearly indicated that highest acid number was obtained from storage Giza 21 and Giza 35 cultivars for 12 months without significant differences between them. While, lowest acid number were recorded from Giza 22 before storage [Fig-3]. The results clearly indicated that highest peroxide number was obtained from storage Giza 21 and Crawford cultivars for 12 months without significant differences between them. While, the lowest peroxide number were recorded from before storage of Giza 22 [Fig-4]. These results in agreement with those reported by Arefi and Abdi [5], Balesevic-Tubic, et al [8], Chuansin, et al [10], Khaliliaqdam, et al [19], Muhammad [23], Tatipata [31].

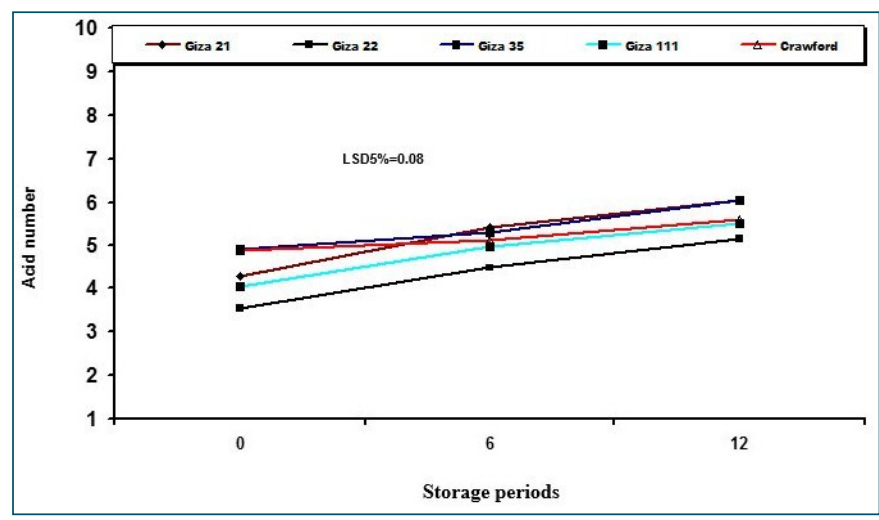

Fig. 3- Averages of acid number as affected by the interaction between storage periods and soybean cultivars.

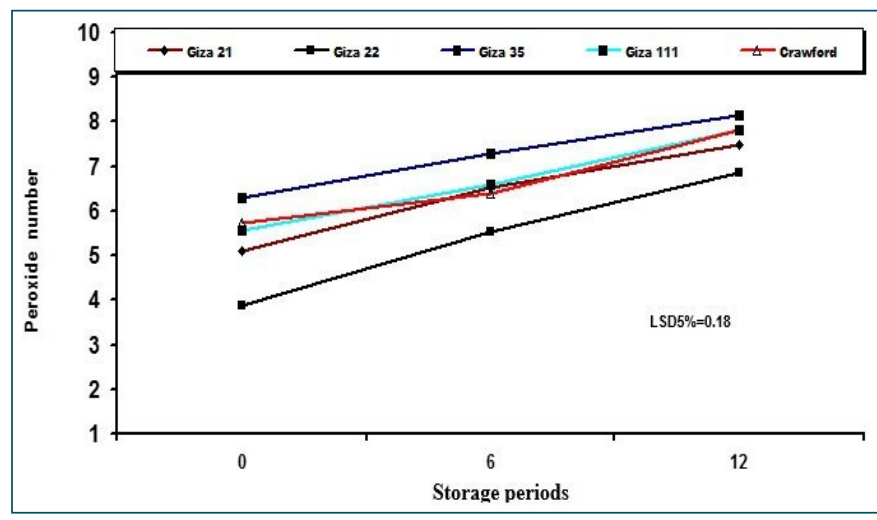

Fig. 4- Averages of peroxide number as affected by the interaction between storage periods and soybean cultivars.

\section{Interaction between Storage Periods and Storage Conditions Effects}

The results clearly showed that pre storage treatment recorded the lowest electrical conductivity followed by storage after 3 months under refrigerator conditions at $10^{\circ} \mathrm{C}$ [Fig-5]. Highest electrical conductivity was recorded from storage for 12 months under ambient conditions. The results clearly showed that pre storage treatment recorded highest moisture percentage followed by storage for 3 months under refrigerator conditions at $10^{\circ} \mathrm{C}$ [Fig-6]. Storage under ambient conditions for 12 months recorded the lowest moisture percentage. Pre storage treatment recorded highest oil percentage followed by storage after 3 months under refrigerator conditions at $10^{\circ} \mathrm{C}$ [Fig-7].

Storage under ambient conditions for 12 months recorded lowest oil percentage. The results clearly showed that pre storage treatment recorded lowest acid number followed by storage for 3 months under refrigerator conditions at $10^{\circ} \mathrm{C}$ [Fig-8]. Storage under ambient conditions for 12 months recorded highest acid number. The results clearly indicated that pre storage treatment recorded lowest peroxide number followed by storage for 3 months under refrigerator conditions at $10^{\circ} \mathrm{C}$ [Fig-9]. 


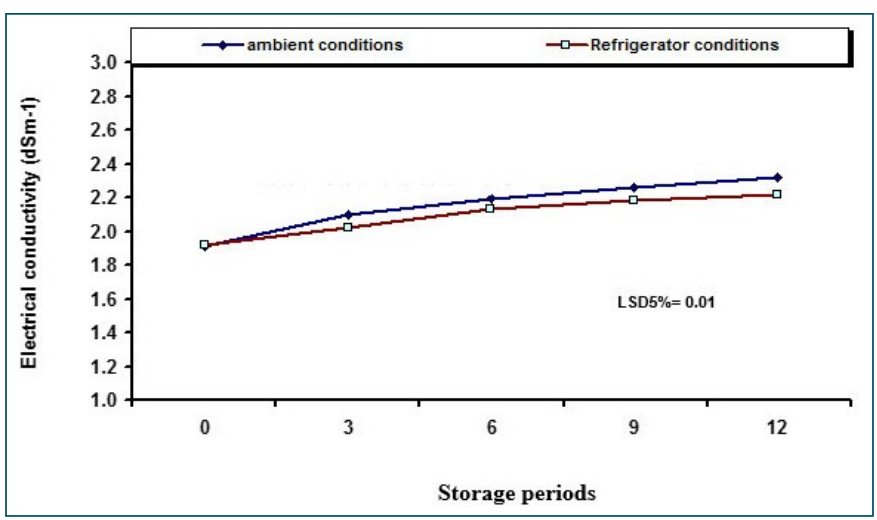

Fig. 5- Averages of electrical conductivity $\left(\mathrm{dsm}^{-1}\right)$ as affected by the interaction between storage conditions and storage periods

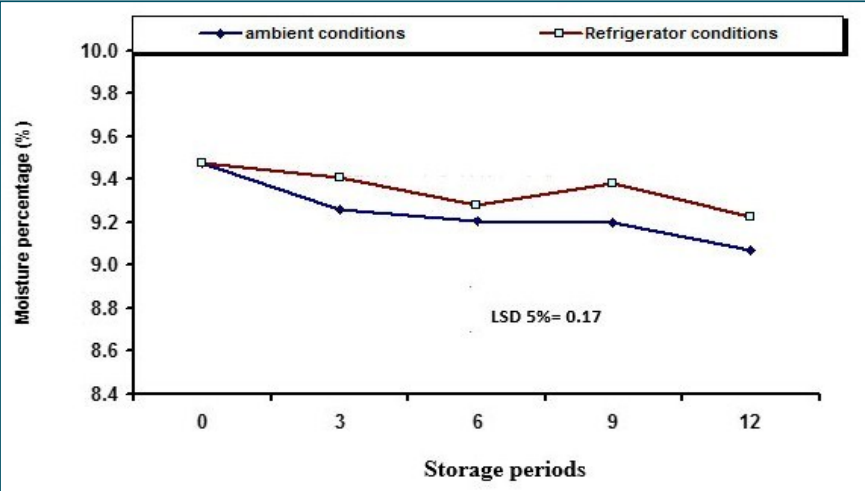

Fig. 6- Averages of moisture percentage (\%) as affected by the interaction between storage conditions and storage periods.

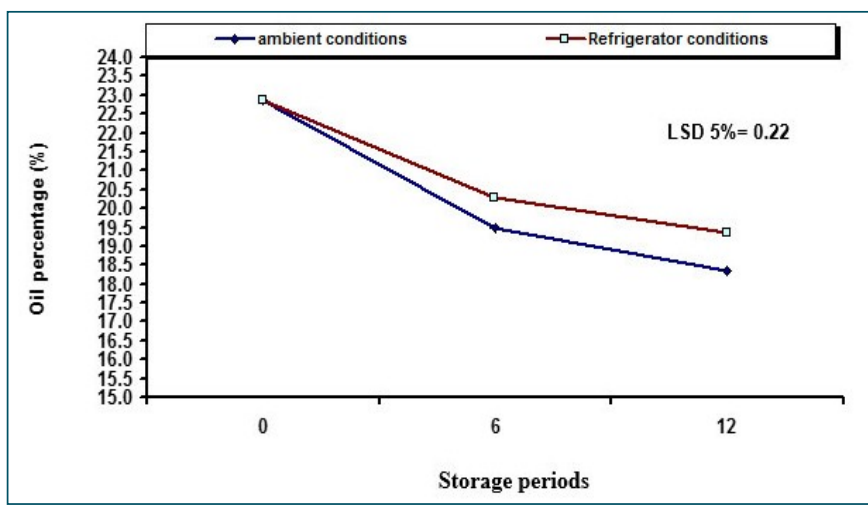

Fig. 7- Averages of oil percentage(\%) as affected by the interaction between storage periods and storage conditions.

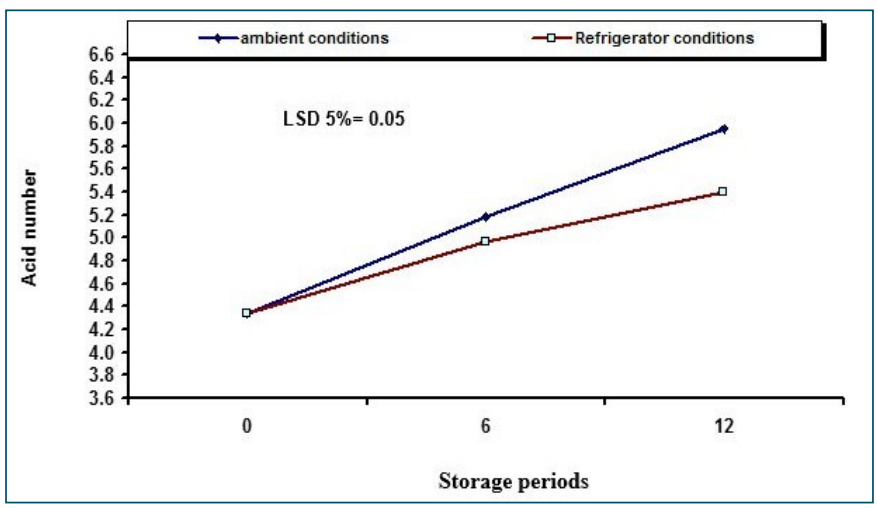

Fig. 8- Averages of acid number as affected by the interaction between storage periods and storage conditions.

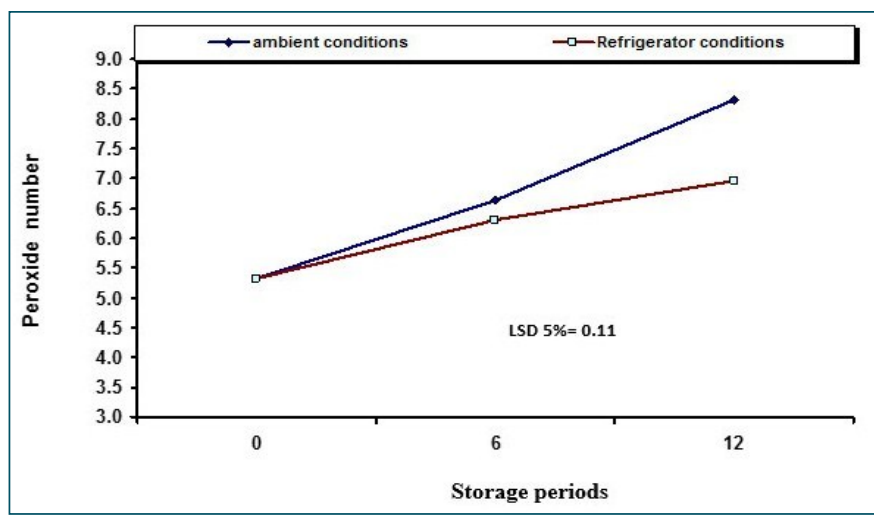

Fig. 9- Averages of peroxide number as affected by the interaction between storage periods and storage conditions

Storage under ambient conditions for 12 months recorded the highest peroxide number. The amount of electrolytes in the soaked water increased as the period of time and the temperature of storage were increased. In this respect Vieira, et al [33] showed that the temperature at which soybean seeds remain during storage may affect the amount of electrolytes in the soaked water and consequently the results of the electrical conductivity test. Moreover, Vijay, et al [35] incubated soybean seeds at two different temperatures of $34^{\circ} \mathrm{C}$ and $40^{\circ} \mathrm{C}$ for varying times. They indicated that soybean viability decreased by increasing storage temperature. These results are in conformity with those reported by Balesevic-Tubic, et al [7], Erandes, et al [13], Jamro, et al [17], Khaliliaqdam, et al [19], Mohammadi, et al [21], Vieira, et al [34].

\section{Interaction between Soybean Cultivars and Storage Conditions Effects}

Electrical conductivity significantly affected due to the interaction between soybean cultivars and storage conditions. Highest electrical conductivity was obtained from storage Crawford cultivar underambient conditions. The lowest electrical conductivity was obtained from storage Giza 21cultivar under refrigerator conditions at $10^{\circ} \mathrm{C}$ [Fig-10].

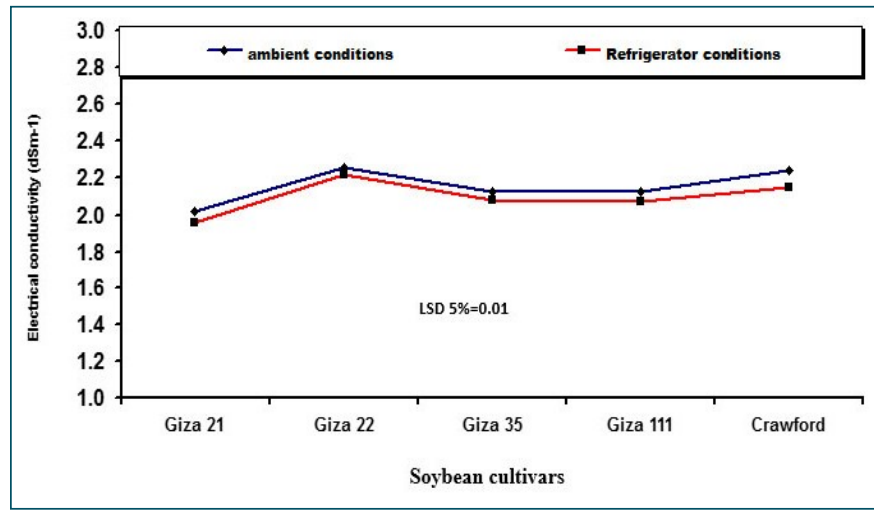

Fig. 10- Averages of electrical conductivity (dSm-1) as affected by the interaction between soybean cultivars and storage conditions.

The results clearly indicated that highest oil percentage was obtained from storage Crawford cultivar under refrigerator conditions $\left(10^{\circ} \mathrm{C} \pm 1\right)$. The lowest oil percentage was obtained from storage Giza 21 and Giza 35cultivars under ambient conditions without significant differences between them [Fig-11]. In this trend, Khaliliaqdam, et al [19] reported that initial viability was same $100 \%$ among DPX and Sahar cultivars. Electrical conductivity had no significant 
difference between DPX and Sahar cultivars but in Shahar, were higher than DPX and EC in Sahar was lower. These results are in conformity with those reported by Arefi and Abdi [5], Chuansin, et al [10], Erandes, et al [13], Khaliliaqdam, et al [19], Tatipata [31].

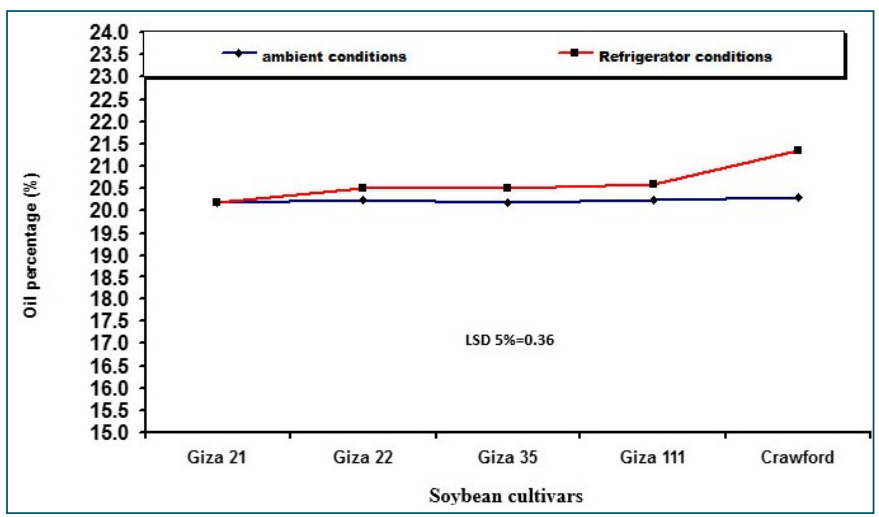

Fig. 11- Averages of oil percentage (\%) as affected by the interaction between soybean cultivars and storage conditions.

\section{Interaction between Storage Periods, Soybean Cultivars and Storage Conditions}

The results clearly showed that highest electrical conductivity was obtained from storage Giza 22and Giza 111 cultivars underambient conditions for 12 months. The lowest electrical conductivity was obtained from pre storage of Giza 21 and Giza 35 cultivars [Fig-12]. In this regard, Tatic, et al [30] noticed that a significant differences between soybean genotypes (Sb1, Sb2, Sb3, Sb4, Sb5 and Sb6) in oil percentage, acid number, peroxide number and moisture percentage. These differences between genotypes might be due to the genetic factors and seed chemical composition influence the expression of seed deterioration and vigor decline. These results are in good agreement with those reported by Balesevic-Tubic, et al [7], Erandes, et al [13], Jamro, et al [17], Khaliliaqdam, et al [19], Mohammadi, et al [21], Vieira, et al [34].

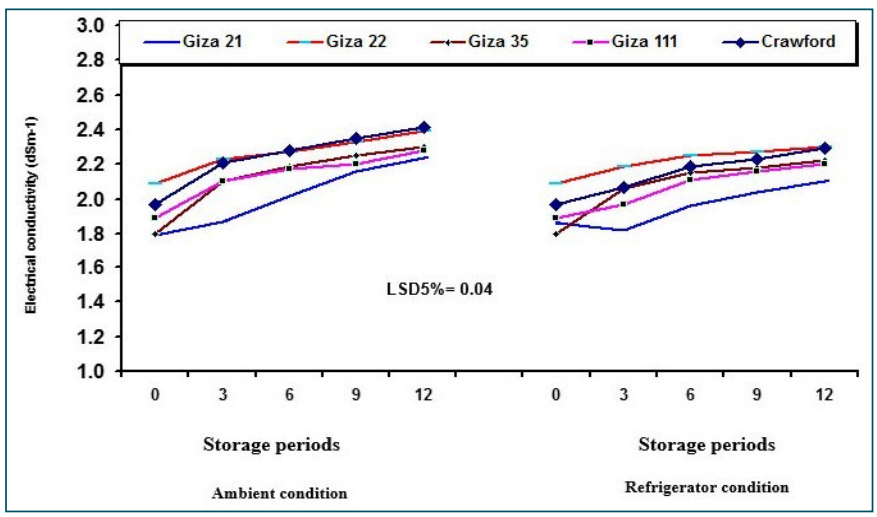

Fig. 12- Averages of electrical conductivity $\left(\mathrm{dSm}^{-1}\right)$ as affected by the interaction between storage periods, soybean cultivars and storage conditions.

\section{Interaction between Storage Periods and Package Materials}

Acid and peroxide numbers significantly affected due to the interaction between storage periods and package materials.

The results clearly showed that pre storage treatment recorded the lowest acid number followed by storage for 3 months [Fig-13]. The highest acid number was recorded from storage soybean cultivars for 12 months seeds in cloth bags. Pre storage treatment recorded the lowest peroxide number followed by storage for 3 months [Fig-
14]. The highest acid number was recorded from storage soybean cultivars for 12 months seeds in plastic bags. The oil peroxide index differed significantly among samples due to the interaction between moisture content, temperature and storage period [3]. These results are in conformity with those reported by Khaliliaqdam, et al [19], Muhammad [23].

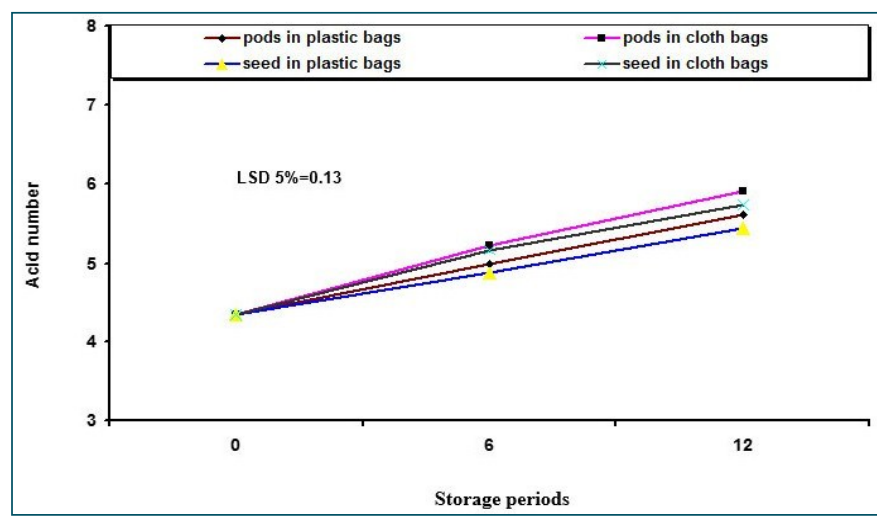

Fig. 13- Averages of acid number as affected by the interaction between storage periods and package materials.

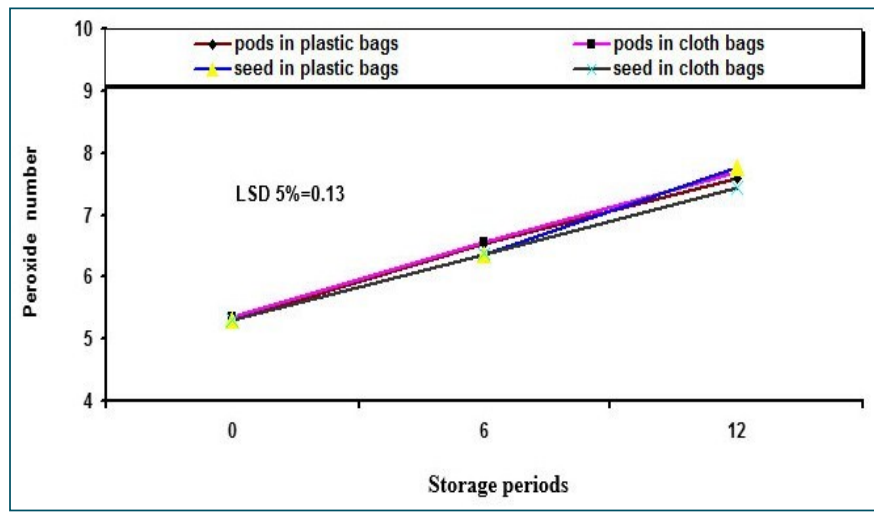

Fig. 14- Averages of peroxide number as affected by the interaction between storage periods and package materials.

Interaction between Soybean Cultivars and Package Materials Highest electrical conductivity was obtained from storage Giza 22 cultivar pods storage in cloth bags or seeds in plastic bags. While, lowest values of electrical conductivity was obtained from Giza 21 cultivar storage as pods in plastic or cloth bags [Fig-15].

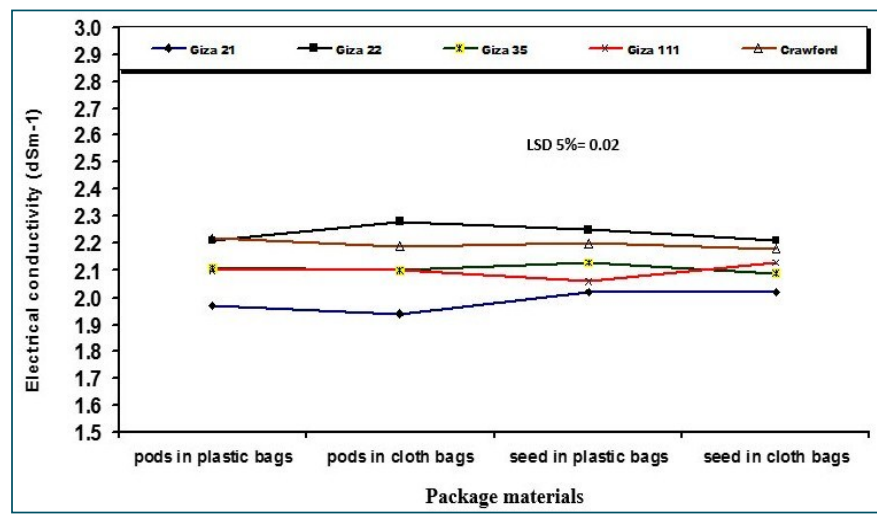

Fig. 15- Averages of electrical conductivity (dSm-1) as affected by the interaction between soybean cultivars fand package materials.

The results clearly showed that the highest acid number were produced from storage Giza 35cultivaras pods or seeds in cloth bags 
[Fig-16]. The lowest acid number was obtained from storage Giza 22cultivarseeds in plastic or cloth bags without significant differences between them. Highest peroxide number was produced from storage Giza 35cultivaras pods in plastic or cloth bags [Fig-17]. The lowest peroxide number was obtained from storage Giza 22cultivarseed in cloth bags. These results are in conformity with those reported by Balesevic-Tubic, et al [7], Erandes, et al [13], Jamro, et al [17], Khaliliaqdam, et al [19], Mohammadi, et al [21].

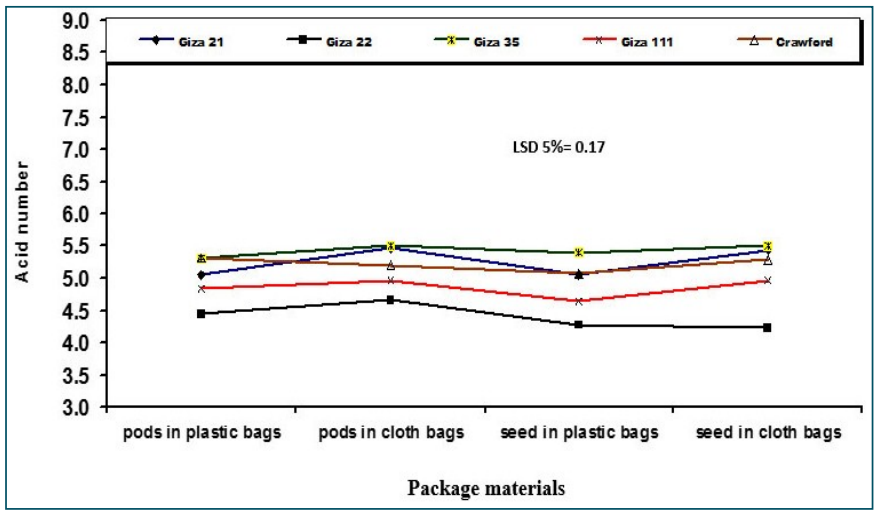

Fig. 16- Averages of acid number as affected by the interaction between soybean cultivars and package materials.

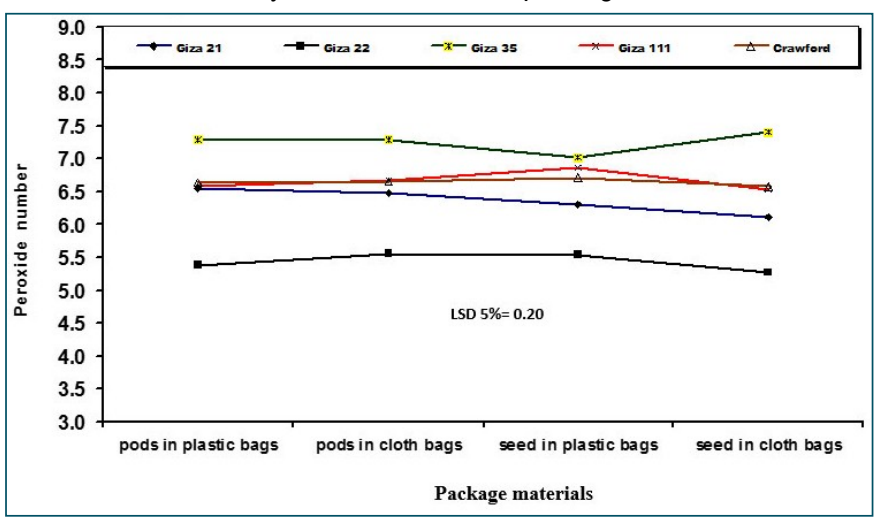

Fig. 17- Averages of peroxide number as affected by the interaction between soybean cultivars and package materials.

\section{Interaction between Storage Periods, Soybean Cultivars and Package Materials}

The results clearly showed that highest electrical conductivity was obtained from storage Giza 22cultivarseed in plastic bags for 12 months.

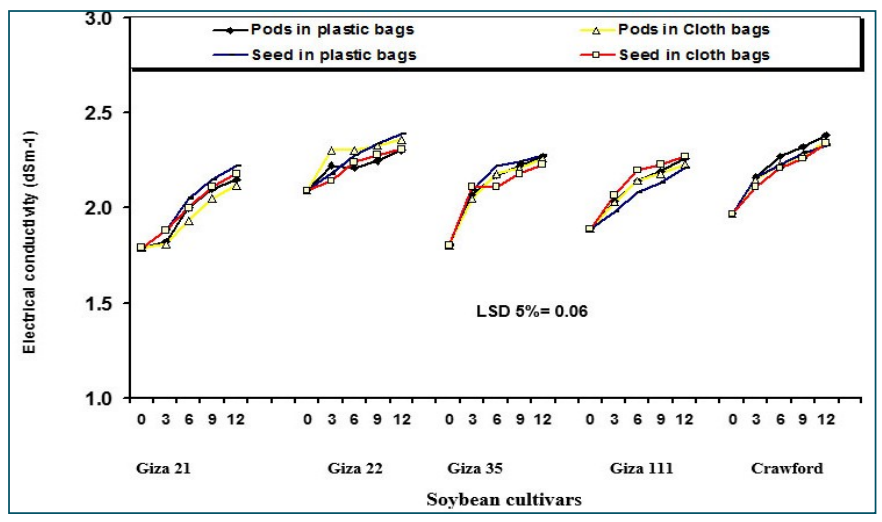

Fig. 18- Averages of electrical conductivity (dSm-1) as affected by the interaction between soybean cultivars, package materials and storage periods.
The lowest electrical conductivity was obtained from pre storage of Giza 21 and Giza 35 cultivars [Fig-18]. The results clearly showed that highest acid number was produced from storage Giza 35 cultivar as pods or seeds in cloth bags for 12 months [Fig-19]. The lowest acid number was obtained from pre storage of Giza 22 cultivar. The results clearly showed that highest peroxide number were produced from storage Giza 35 cultivar as seed in cloth bags for 12 months [Fig-20]. The lowest peroxide number was obtained from pre storage of Giza 35 cultivar. These results are in good agreement with those reported by Balesevic-Tubic, et al [7], Erandes, et al [13], Jamro, et al [17], Khaliliaqdam, et al [19], Mohammadi, et al [21], Vieira, et al [34].

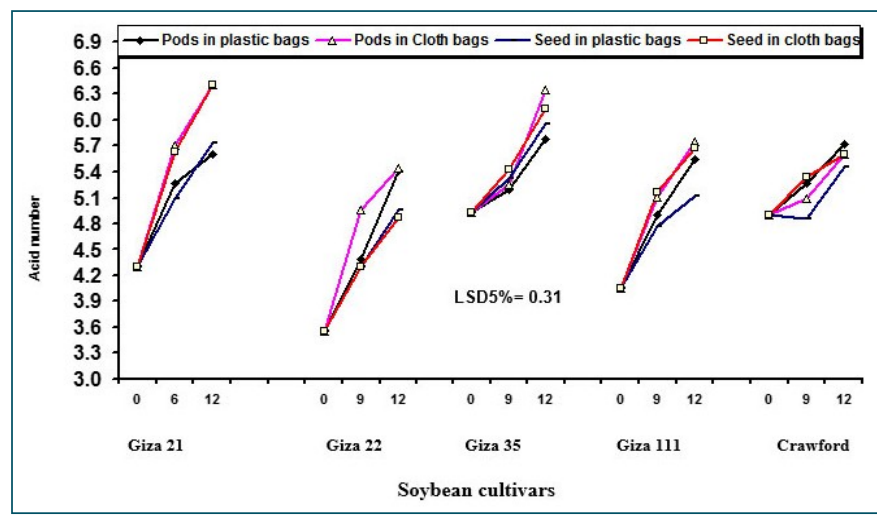

Fig. 19- Averages of acid number as affected by the interaction between storage periods, soybean cultivars and package materials.

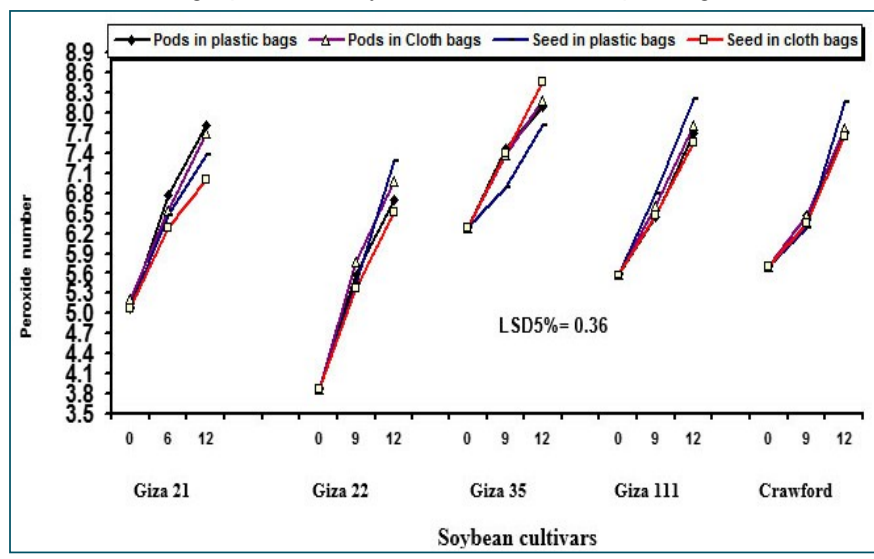

Fig. 20- Averages of peroxide number as affected by the interaction between storage periods, soybean cultivars and package materials

\section{Interaction between Storage Conditions and Package Materials}

The results clearly showed that highest electrical conductivity was obtained from storage soybean cultivars as pods in cloth bags under refrigerator conditions $\left(10^{\circ} \mathrm{C} \pm 1\right)$. The lowest electrical conductivity was obtained from storage soybean cultivars pods in cloth bags underambient conditions [Fig-21].

In this respect, Chuansin, et al [10] found that soybean seeds were stored in Metallized film bags and Aluminum foil bags keep water activity and seed moisture content in low level could delay seed quality deterioration followed by Polypropylene bags and woven bag. The oil peroxide index differed significantly among samples due to the interaction between moisture content, temperature and storage period [3]. These results in good harmony with those reported by Balesevic-Tubic, et al [7], Erandes, et al [13], Jamro, et al [17], Khaliliaqdam, et al [19], Mohammadi, et al [21]. 


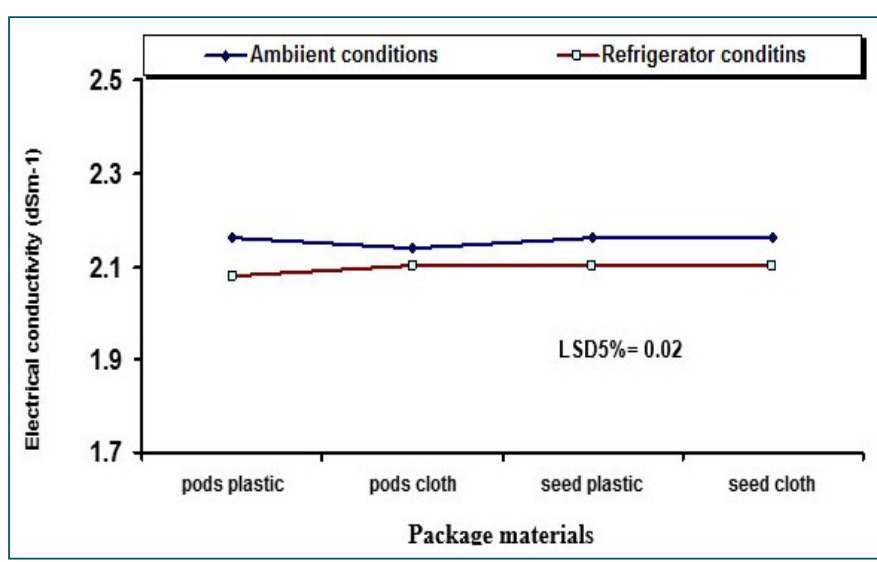

Fig. 21- Averages of electrical conductivity (dSm-1) as affected by the interaction between storage conditions and package materials

\section{Conclusion}

The results indicated that for maximizing soybean seed quality, it could be storage Giza 111 cultivar under refrigerator conditions $\left(10^{\circ} \mathrm{C} \pm 1\right)$ aspods or seeds in cloth bags for 3 months.

\section{Acknowledgment}

Sincere and gratitude thanks to Prof. Dr. Ali E. Sharief, Agronomy Dep., Faculty of Agriculture, Mansoura University, for possible help and extraordinary effort during the achievement of this investigation andhis guidance and encouragement during the extraordinary effort during this work.

\section{References}

[1] Association of Official Agric. Chem. (1996) Official Methods of Analysis, Washington, USA.

[2] Alencar E.R. and Faronil R.D. (2011) Recent Trends for Enhancing the Diversity and Quality of Soybean Products, 47-67.

[3] Alencar E.R., Faronil R.D., Peternellil A., Silva M.T.C. and Costa A.R. (2010) Revista Bras. Eng. Agríc. Ambiental., 14(3), 303308.

[4] Gupta A.A. and Aneja K.R. (2004) Seed Research, 32(1), 2632.

[5] Arefi H.M. and Abdi N. (2003) Iranian J. Rangelands and Forests Plant Breeding and Genetic Res., 11, 105-125.

[6] Arif M. (2006) Khutab Al Nabi (Prophets Sermons) Collection, Compilation, Research, Interpretation, Explanation, Unraveling Strange Words \& Determining the Date, Ph.D. Dissertation, NWFP Agricultural University Peshawar, Pakistan.

[7] Balesevic-Tubic S., Malencic D., Tatic M. and Miladinovic J. (2005) Hellia, 28(42), 107-114.

[8] Balesevic-Tubic S., Tatic M., Dordevic V., Nikolic Z. and Dukic V. (2010) Helia, 33(52), 153-160.

[9] Charjan S. and Tararj L. (1992) Indian Journal Agriculture Sciences, 62, 500-502.

[10]Chuansin S., Vearasilp S., Srichuwong S. and Pawelzik E. (2006) Conference on International Agricultural Research for Development, University of Bonn, Bonn, Germany.

[11]Doijoide S.N. (1988) Seed Research, 1, 245-247.

[12]El-Abady M.I., El-Emam A.A.M., Seadh S.E. and Yousof F.I. (2012) Research Journal of Seed Science, 3, 1-11.

[13]Erandes R.D., Leda R.D.F., Luiz A. and Macro T.C. (2010)
Revista Brasileira de Engenharia Agricola, 14 (3), 303-308.

[14]Ghasemnezhad A. and HonermeierB. (2007) Int. J. Plant Prod., 3(4), 41-50.

[15]Hou H.J. and Chang K.C. (2004) Journal of Agricultural and Food Chemistry, 46, 4798-4805.

[16]International Seed Testing Association (1996) Seed Science and Technology, 24, 1-335.

[17]Jamro G.H., Hatam M., Jamali L.A. and Agha S.K. (2005) Agri. Mech. in Asia, Africa and Latin America, 36, 15-17.

[18]Kalavathi D.K. and Sundareswaran S. (1994) Madras Agricultural Journal, 81(11), 612-615.

[19]Khaliliaqdam N., Soltani A., Latifi N. and Gaderi F.F. (2012) American-Eurasian Journal of Agriculture and Environments Sciences, 12(2), 224-230.

[20]Milošević M. and Malešević M. (2004) Naučni institut za ratarstvo i povrtarstvo, Novi Sad, 110-114.

[21]Mohammadi H., Soltani A., Sadeghipour H.R. and Zeinali E. (2011) International Journal of Plant Production, 5(1), 65-70.

[22]Monira U.S., Amin M.H.A., Marin M. and Mamun M.A.A. (2012) Bangladesh Research Publications Journal, 7(4), 421-427.

[23]Muhammad A. (2008) Effect of Planting Dates and Storage on Yield and Quality of Indigenous Land Races and Improved Varieties of Soyabean, Ph.D. Thesis, Agri. Uni. Peshawar, Pakistan.

[24]Owolade O.F., Olasoji J.O. and Afolabi C.G. (2011) African Journal of Plant Science, 5(15), 873-877.

[25]Shanmugavel S.A. and Dadlani M. (1995) Seed Research, 23 (2), 61-66.

[26]Sharma S., Gambhir S. and Manshi S.K. (2007) Asian Journal of Plant Sciences, 6(3), 502-507.

[27]Shelar V.R., Shaikh R.S. and Nikam A.S. (2008) Agric. Rev., 29 (2), 125-131.

[28]Šimić B., Popović R., Sudarić A., Rozman V., Kalinović I. and Ćosić J. (2007) Agric. Conspectus Sci., 72(3), 211-213.

[29]Simic B., Sudaric A., Liovic I., Kalinovic I., Rozman V. and Cosic V. (2006) 9th International Working Conference on Stored Product Protection, 59-63.

[30]Tatic M., Balesevic-Tubic S., Dordevic V., Miklic V., Vujakovic M. and Dukic V. (2012) Helia, 35(56), 119-126.

[31]Tatipata A. (2009) Journal of Agricultural Technology, 5(1), 5164.

[32]Venkatareddy D.M., Bommegowda A. and Paramesh D.S. (1992) Seed Tech. News, 22(2), 41-46.

[33]Vieira R.D., TeKrony D.M., Egli D.B, Bruenning W.P. and Panobianco M. (2008) Sci. Agric. (Piracicaba, Braz.), 65(5), 496-501.

[34]Vieira R.D., Tekrony D.M., Egli D.B. and Rucker M. (2001) Seed Science and Technology, 29, 599-608.

[35]Vijay D. and Dadlani M. (2009) Plant Molecular Biology, 22, 282 -291 . 